\title{
コレラトキシンのラット腎同種移植に抢ける免疫抑制効果
}

\author{
防衛医科大学校泌尿器科学講座（主任：中村宏教授） \\ 浅 野友 彦
}

\section{THE IMMUNOSUPPRESSIVE EFFECT OF CHOLERA TOXIN ON RAT RENAL ALLOGRAFT}

\author{
Tomohiko Asano \\ Department of Urology, National Defense Medical College \\ (Director: Prof. H. Nakamura)
}

Immunomodulatory effects of cholera toxin (CT) were investigated in a rat model, and the effects of CT on rat renal allograft (from Lewis rat to WKAH rat) were also examined. The results are: 1) The number of lymphocytes in the thymus, spleen and peripheral blood was remarkably decreased after 7 day administration of CT $(0.1$ and $0.2 \mathrm{mg} / \mathrm{kg} /$ day $)$, but the number of red blood cells and neutrophils was not decreased. 2) CT suppressed mixed lymphocyte reaction (MLR) in a dose dependent fashion, and \%suppression reached $97 \%$ at the concentration of $10 \mu \mathrm{g} / \mathrm{ml}$. The later the time of addition of CT to MLR, the less became this effect. 3) In the control group, the mean survival time (MST) after transplantation was $8.5 \pm 0.3$ (Mean $\pm \mathrm{SE}$ ) days. CT, given 1 day before transplantation, did not prolong MST. In the group to which CT was given daily for 14 days from the day of transplantation, MST was prolonged with the increase of CT. CT at the dosage of $0.2 \mathrm{mg} / \mathrm{kg} / \mathrm{day}$ prolonged MST (16.2 \pm 3.2 days) significantly $(\mathrm{p}<0.05)$, where treated with $\mathrm{CT}$ from the 3 rd day after transplantation, MST (10.3 \pm 1.3 days) was not significantly prolonged. From the above findings, CT seems to act mainly on the early phase of acute rejection and prolongs rat renal allograft survival.

Key words: cholera toxin, renal transplantation, immunosuppression

要旨：コレラトキシン（以下 CT) が免疫機能に及ぼす効果についてラットを用い, in vivo, in vitroで 検討を加えた。ささらに, WKAH ラットをドナー, Lewis ラットをリシピエントとするラット堅同種移植 モデルを用いて CT の拒絶反応抑制効果について検討を加え，以下の結果を得た，1）CT は胸腺，脾， 未梢血中のリンパ球数を著明に減少させるが，赤血球数，好中球数は減少させず，骨髄抑制作用はみら れなかった。 2) CT はリンパ球混合培養反応を濃度依存性に抑制し，CT $10 \mu \mathrm{g} / \mathrm{ml}$ の時の\%抑制率は 97\%であった。 また，この抑制効果はCT の添加時期により経時的に減弱し，時間依存性を示した。 3）


回投与した群では生存日数の延長はみられなかった。CT を14日間連続投与した群では投与量の増加と ともに生存日数が延長する傾向がみられ， $0.2 \mathrm{mg} / \mathrm{kg}$ 投与群では $16.6 \pm 3.2$ 日と有意に $(\mathrm{p}<0.05)$ 延長し た。また，移植後第 3 日目から CT $0.2 \mathrm{mg} / \mathrm{kg}$ 投与した群では生存日数は $10.3 \pm 1.3$ 日と有意な生存日 数の延長はみられなかった。 以上の結果から, CT は拒絶反応の特に初期に作用し，拒絶反応を抑制する ものと思われた。

キーワード：コレラトキシン，腎移植，免疫抑制

\section{緒言}

腎移植の成績は, 1960年代のアザチオプリン，ステ ロイド，抗リンパ球血清グロブリン等による免疫抑制 の時代に比べ，1978年のシクロスポリンの登場以降飛 躍的に向上した ${ }^{11}$.しかしながら,シクロスポリンも腎
毒性，肝毒性，高血圧等の副作用を有することが明か となり,な拉より強力で, より副作用の少ない新しい 免度抑制剂を求めて研究開発が進められている。わが 国でも FK-506 ${ }^{2}$ や15-deoxy spergualin ${ }^{3}$ 等の新しい免 疫抑制剂が発見され，すでに臓器移植の臨床に一部用 
いられつつある。

一方コレラトキシン (CT) は，コレラ菌から分泌さ れる分子量約86,000の蛋白であるが4), Concanavalin A や phytohemagglutinin に対するリンパ球の幼若化 反応を抑制したり ${ }^{5)}$ ，抗体産生を調節したりする゙ など の免疫抑制作用を有することが報告されている。本研 究では臓器移植に打ける CT の免疫抑制効果につい て，ラットの腎同種移植をモデルに用いて in vitro 及 び in vivo の双方から検討した。

\section{対象及び方法}

A.ラットの免疫系に及ぼす影響について

1.ラット胸腺, 脾, 末梢血血液像に及ぼす影響につ いて

Lewis ラット（雄性， 6 週齢，体重約 $150 \mathrm{~g}$ ）を 3 群 に分け, 以下のように CT(コルトックス, 生化学工業) を 7 日間連続皮下投与した。

第 1 群 $(\mathrm{n}=7)$ 生食水のみ

第 2 群 $(\mathrm{n}=7)$ CT $0.1 \mathrm{mg} / \mathrm{kg} /$ day

第 3 群 $(\mathrm{n}=7)$ CT $0.2 \mathrm{mg} / \mathrm{kg} /$ day

$\mathrm{CT}$ 投与開始後第 7 日目に採血を行い赤血球数，白 血球数、リンパ球数を測定した。また第 7 日目に犠死 せしめ, 胸腺, 脾を摘出しその質量を測定し, ホルマ リン固定の後パラフィン包埋し，へマトキシリン・エ オジン染色を行い病理組織学的検討を加えた。

2. リンパ球混合培養 (mixed lymphocyte reaction, MLR）に及ぼす影響について

Lewis ラットを responder, WKAH ラットを stimulator とする one way MLRを行った。リンパ球は無 菌的に頸部リンパ節を採取し, medium (RPMI 1640) 中で細切しステンレス・メッシュを通して細胞浮遊液 とした. stimulatorは, 最終濃度 $25 \mu \mathrm{g} / \mathrm{ml}$ のマイトマ

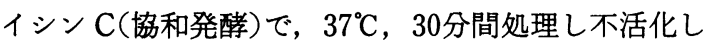
た後, medium で 3 回洗浄した. $1 \times 10^{5}$ 個の responder cell $(0.1 \mathrm{ml})$ と $2 \times 10^{5}$ 個の stimulator cell $(0.1$ ml)を 96 well 丸底タイタープレート (Nunc，デンマー ク）で混合培養した。 final mediumとして10\%FBS (GIBCO，Lot. No. $28 \mathrm{~K} 6155$ ) 加 RPMI 1640 (GIBCO), $25 \mathrm{mM}$ HEPES buffer, $5 \times 10^{-5} \mathrm{M} 2$. メルカプトエタノール, ペニシリン 100 unit $/ \mathrm{ml}$, スト レプトマイシン $100 \mu \mathrm{g} / \mathrm{ml}$ を用いた. $37^{\circ} \mathrm{C}, 5 \% \mathrm{CO}_{2}$ で 5 日間培養を行い, 培養終了 16 時間前に ${ }^{3} \mathrm{H}$-thymidine $\left({ }^{3} \mathrm{H}-\mathrm{TdR}\right) 0.5 \mu \mathrm{Ci} /$ well (デュポソ NEN リサーチ・プ ロダクト）を添加し，セル・ハーベスターで細胞をグ ラス・フィルター上に採取し, 乾燥後液体シンチレー
ション・カウンター（アロカ LSC 673）で3 H-TdR の 取り込みを測定した。

CT の濃度が MLRに及ぼす影響について検討を加 えるために, 最終濃度が $0.01,0.1,1,10 \mu \mathrm{g} / \mathrm{ml}$ とな るようにCTを培養初期から添加し, ${ }^{3} \mathrm{H}-\mathrm{TdR}$ の取り 込々を測定，これを\%抑制率として表した。また， CT の添加の時期が MLR に及ぼす影響について調べるた めに, CT を培養開始後 $24,48,72,96$ 時間目に添加し （最終濃度 $0.1,1,10 \mu \mathrm{g} / \mathrm{ml}$ ), 添加の時期による ${ }^{3} \mathrm{H}$ $\mathrm{TdR}$ の取り込みの変化を調べた。尚, 本実験は triplicateで 3 回行いその平均値を比較した.

$$
\begin{array}{r}
\% \text { 抑制率 }=\left(1-\frac{\mathrm{CT} \text { 添加時の取り込み }(\mathrm{CPM})}{\mathrm{CT} \text { 非添加時の取り込み }(\mathrm{CPM})}\right) \\
\times 100(\%)
\end{array}
$$

B. CT のラット腎同種移植に扮ける免疫抑制効果 について

実験動物は, 近交系の WKAH ラット（RT-1 $\left.{ }^{\mathrm{k}}\right)$ をド ナー, Lewis ラット（RT-11)をレシピェントとして用 いた。 ドナー,レシピェントともに雄性, 週齢 $8 \sim 12$ 週, 体重200〜250g のものを用いた. ラット腎同種移植 はLee らの方法に基づいて行った。すなわちネンブ タール麻酔下にドナー腎を大動脈及び下大静脈の部位 で切除, 摘出し，これを各々リシピエントの大動脈と 下大静脈に8-0ナイロン系で端側に吻合した。尿路の再 建は, ポリェチレン・チューブ(外径 $0.61 \mathrm{~mm}$, 内径 0.28 $\mathrm{mm}$, 夏目製作所)をステントに用いて尿管尿管端々吻 合を行った。腎同種移植終了後, レシピェントの両側 固有腎を摘出した。移植腎拒絶の判定は, 腎移植後 7 日目に血清クレアチニンの測定, 移植腎の生検を行い, これらのデータと腎移植後のラットの生存日数により 行った。

CT 生理的食塩水に溶解したものを用い，下記の 群に分けて投与した。

第 1 群. CT 非投与群 $(\mathrm{n}=8)$

第 2 群 下記の量の CT 移植前日に 1 回静脈内投 与した群
(1) $0.1 \mathrm{mg} / \mathrm{kg} \quad(\mathrm{n}=4)$
(2) $0.2 \mathrm{mg} / \mathrm{kg} \quad(\mathrm{n}=7)$

第 3 群 下記の量の CT を移植当日から移植後 14 日 目まで連続皮下投与した群

(1) $0.05 \mathrm{mg} / \mathrm{kg} / \mathrm{day}(\mathrm{n}=6)$

(2) $0.1 \mathrm{mg} / \mathrm{kg} /$ day $(\mathrm{n}=6)$

(3) $0.2 \mathrm{mg} / \mathrm{kg} /$ day $(\mathrm{n}=5)$ 
図 1 CT 投与群, 非投与群における胸腺質量

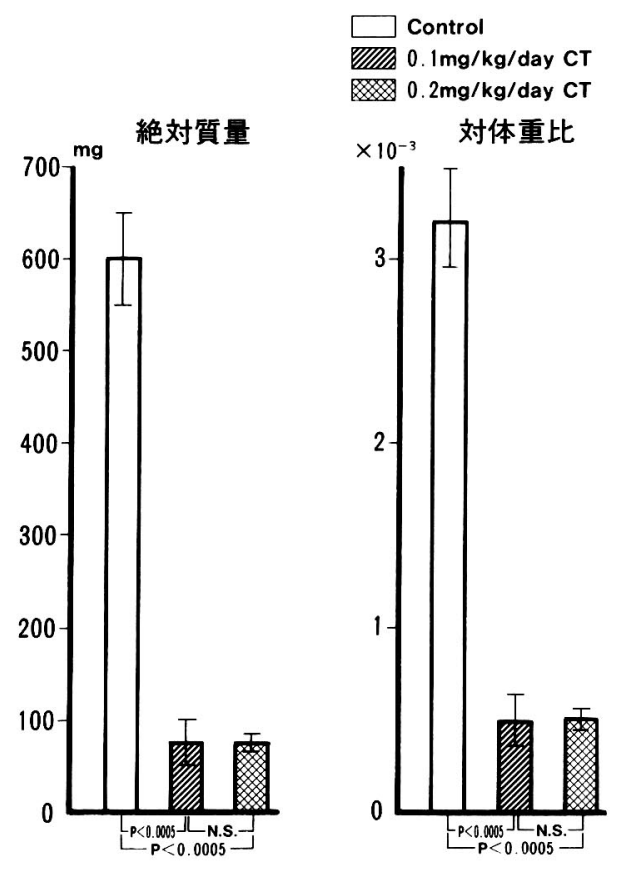

第 4 群 CT $0.2 \mathrm{mg} / \mathrm{kg} / \mathrm{day}$ を移植後 3 日目から 2 週間連続皮下投与 $(n=5)$

\section{結 果}

A. ラットの免疫系に及ぼす効果について

1. ラット胸腺，脾，血液像に及ぼす影響について

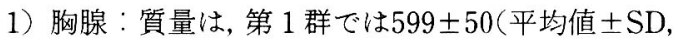
以下同様) $\mathrm{mg}$ であったのに対して第 2,3 群では各々 $74 \pm 24 \mathrm{mg}, 74 \pm 9 \mathrm{mg}$ と著明に減少した。また，対体重 比(臓器質量/体重)で比べても第 1 群では $3.2 \pm 0.28 \times$ $10^{-3}$ であったのに対し，第 $2 ， 3$ 群では各々 $0.49 \pm$ $0.14 \times 10^{-3}, 0.51 \pm 0.06 \times 10^{-3}$ と著明に低下していた (図 1 ). 病理組織学的には, CT 投与群では, 皮質領域 のリンパ球は著明に減少し, 多数の foamy cellによっ て置さ換えられていた。また胸腺髄質領域もリンパ球 の減少を認めたが，皮質に比べるとその変化は軽度で あった (写真 1 ).

2）脾：質量は，第 1 群では506士50mgであったの に対して，第 $2 ， 3$ 群では各々 $300 \pm 48 \mathrm{mg}, 234 \pm 62 \mathrm{mg}$ と著明に減少していた。 また，対体重比でも第 1 群で

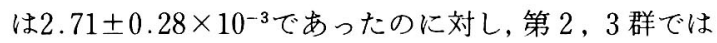
$2.00 \pm 0.25 \times 10^{-3}, 1.26 \pm 0.43 \times 10^{-3}$ と著明に低下し ていた(図 2 ). 病理組織学的には, CT 投与群の脾は, 第 2,3 両群とも非投与群と比べ白脾髄の中心部（T
写真 1 胸腺の病理組織学的所見 ( $\mathrm{HE}$ 染色)：M：䯣 質, C : 皮質

対照群 (A) に比しCT $0.2 \mathrm{mg} / \mathrm{kg}$ 投与群 (B) では 皮質領域のリンハ球は著明に減少し, 多数の foamy cellによって置き換光られている。髄質領域のリン 年球も減少している。(a：×32, b：×80)

A



B

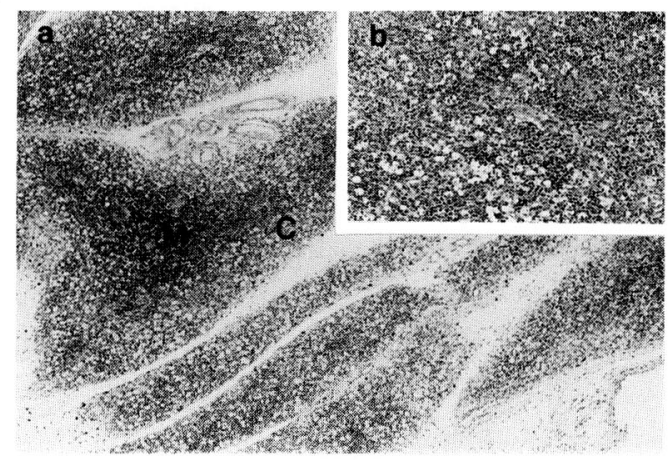

細胞領域) で著明な, 周辺部 (B 細胞領域) では軽度 のリンパ球の減少がみられたが，胸腺でみられた変化 に比べると全体的にその変化は軽度であった。また赤 脾髄は非投与群と比べて明らかな変化は認められな かった（写真 2 ).

3）血液像（図 3 ）：赤血球数では, 第 1 群 $699 \pm 48 \times$ $10^{4} / \mathrm{mm}^{3}$ ，第 2 群 $692 \pm 34 \times 10^{4} / \mathrm{mm}^{3}$ ，第3群 $651 \pm 58 \times$ $10^{4} / \mathrm{mm}^{3}$ と 3 群間に有意差は認められなかった。白血 球数では, 第 1 群 $7,757 \pm 2,219 / \mathrm{mm}^{3}$ ，第 2 群6,500土 $1,084 / \mathrm{mm}^{3}$, 第 3 群 $4,557+1,522 / \mathrm{mm}^{3}$ と第 3 群で有 意に $(\mathrm{p}<0.005)$ 減少していた。リンパ球数では，第

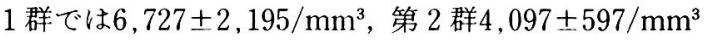
$(\mathrm{p}<0.05)$ ，第 3 群 $2,384 \pm 787 / \mathrm{mm}^{3} （ \mathrm{p}<0.005 ）$ と第 2, 3 群で有意に減少していた。多核白血球数は，第 1 群 $499 \pm 227 / \mathrm{mm}^{3}$, 第 2 群 $1,878 \pm 389 / \mathrm{mm}^{3}$, 第 3 群 $1,640 \pm 914 / \mathrm{mm}^{3}$ と第 1 群と比べて第 2,3 群では有 
図2 CT 投与群，非投与群における脾質量

絶対質量

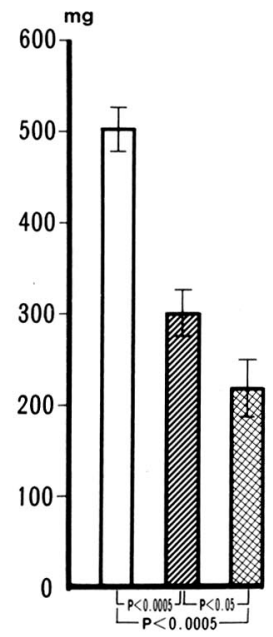

Control

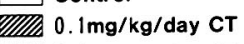

$0.2 \mathrm{mg} / \mathrm{kg} /$ day CT 対体重比

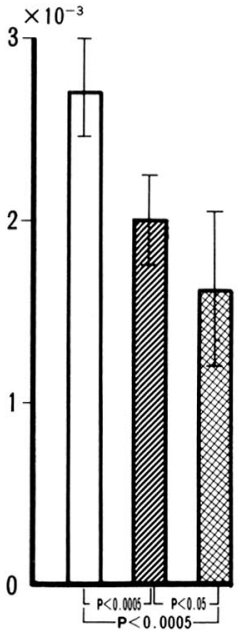

写真 2 脾の病理組織学的所見 (HE 染色)：W：白脾 髄, $\mathrm{R}$ : 赤脾髄

非投与群 (A) に比し CT $0.2 \mathrm{mg} / \mathrm{kg}$ 投与群 (B) で は白脾髄の中心部で著明なリンパ球の減少がみら れ，周辺部でも軽度の減少を見る。（a：×32, b：× 80)

A

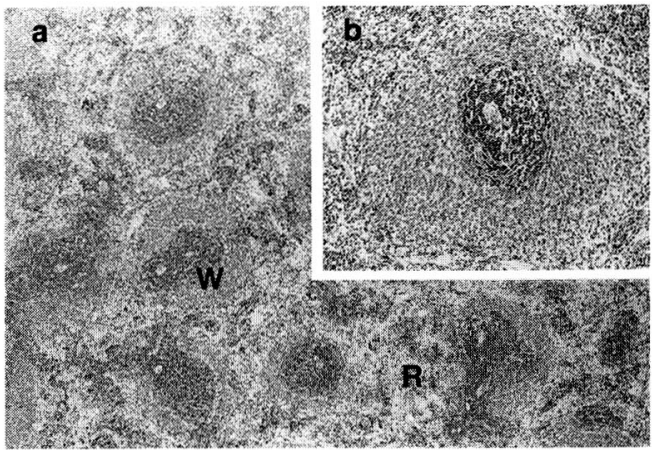

$\mathbf{B}$

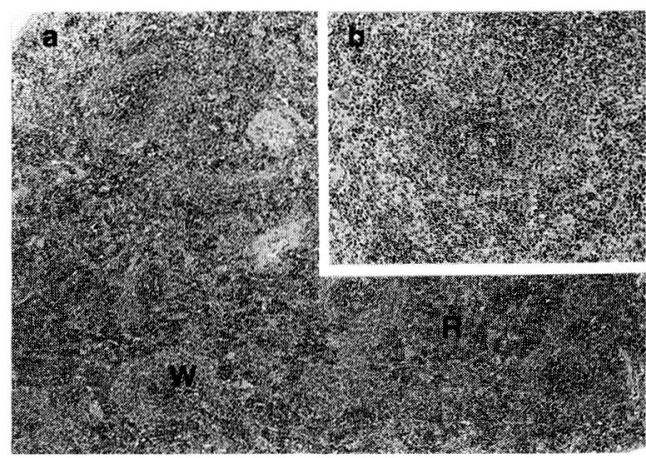

意に（p<0.05）増加していた。

2. MLRに及ほすす効果について

MLR の培養初期から CT を添加した場合, CT 濃度 が $0.01,0.1 ， 1,10 \mu \mathrm{g} / \mathrm{ml}$ の時の取り込みの\%抑制率

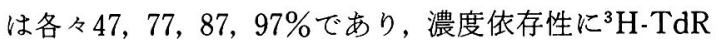
の取り込みを抑制した（図 4).

培養開始後 $24 ， 48 ， 72 ， 96$ 時間後にCT を添加した 場合, その\%抑制率は CT 濃度が $0.1 \mu \mathrm{g} / \mathrm{ml}$ の場合

図 3 CT 投与群，非投与群に打ける末梢血血液像

Total WBC

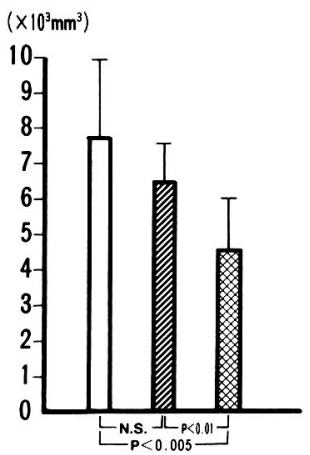

Lymphocytes

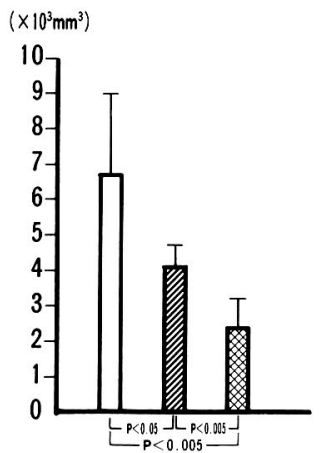

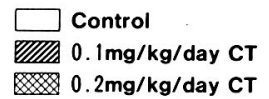

PMNS

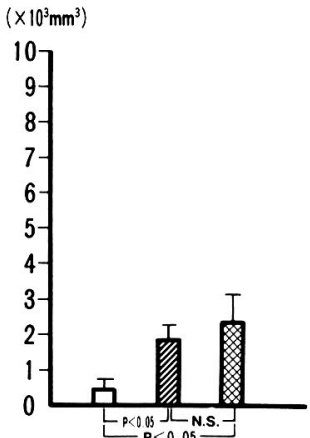


図 4 MLR に対する各種濃度 CT の効果

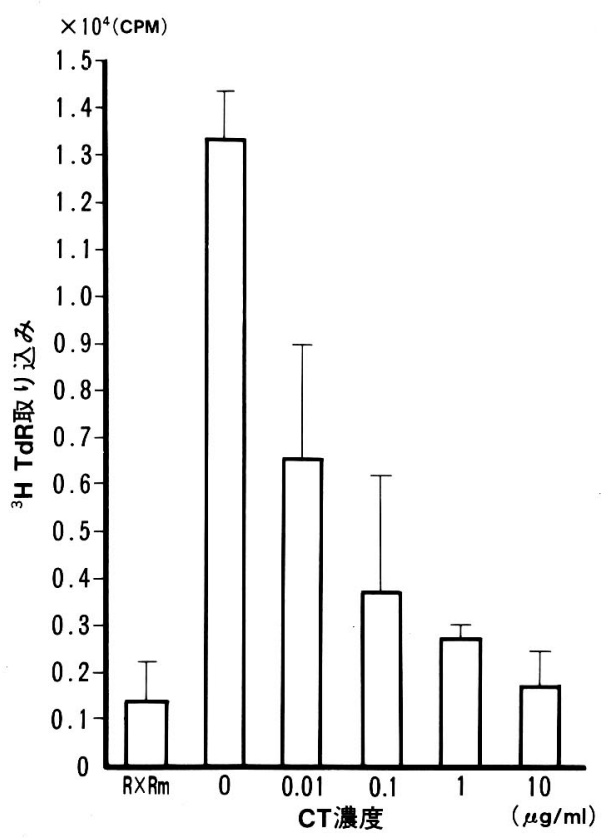

各々 $63 ， 40 ， 24 ， 23 \%$ であり，培養後期に添加するほ ど3 H-TdRの取り込㕛に対する抑制効果は減少する経 時的減少を示した。CT 濃度が $1 \mu \mathrm{g} / \mathrm{ml}$ における\%抑制 率は56，51，35，3\%であり，10 $\mathrm{g} / \mathrm{ml}$ では，74，48， 49，21\%と同様の傾向がみられた(㘠 5 )。尚，トリパ ンブルーによる dye exclusion test の結果, CT $10 \mu \mathrm{g} /$ $\mathrm{ml}$ の濃度に扣いてもリンパ球の viabilityには影響は みられなかった。
写真 3 移植後 7 日目腎生検 (CT 非投与群) ( $\mathrm{HE}$ 染 色）：間質へのリンパ球，単球を主体とする細胞浸 潤，康細管の変性壊死，䒺球体には多核白血球，リ ンパ球, 単球の浸潤と内皮細胞の増殖を見る. (a: $\times 80, b: \times 320)$



B. CTのラット腎同種移植に対する免疫抑制効果 について

第 1 群では平均生存日数は $8.5 \pm 0.3$ 日で, 術後 7 日 目の血清クレアチニン值は6.0 $0.5 \mathrm{mg} / \mathrm{dl}$ であった. また術後 7 日目に行った移植腎の生検では, 間質への 中等度の細胞浸潤, 糸球体, 尿細管の変性壊死など典 型的な急性拒絶反応の像がみらられた(写真 3 ). 第 2 群 の CT 0.1, 0.2 $\mathrm{mg} / \mathrm{kg}$ の移植前日 1 回投与群の平均生 存日数は各々 $9.4 \pm 0.9,8.6 \pm 1.0$ 日と CT 非投与群と 比べて生存日数の延長はみられなかった(表 1 ). 第 3 群の連続投与群では，0.05, 0.1, 0.2 mg $/ \mathrm{kg} / \mathrm{day}$ 投与 群の平均生存日数は各々 $10.6 \pm 0.6,12.3 \pm 1.0,16.6 \pm$

図 5 MLRに対する CT 添加時期の影響

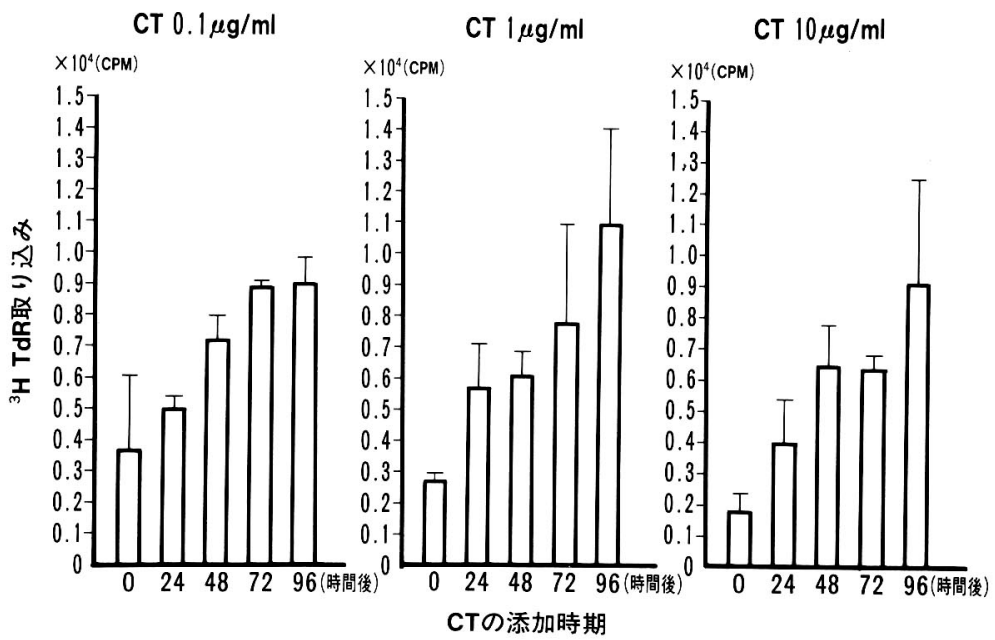


表 1 CT 投与群のラット腎同種移植後生存日数

\begin{tabular}{|c|c|c|c|c|c|}
\hline 群 & & $\mathrm{CT}(\mathrm{mg} / \mathrm{kg})$ & 生存日数(日) & Mean $\pm S E$ & $P$ value \\
\hline 第 1 群 & & 0. $\quad(n=8)$ & $7,8,8,8,9,9,9,10$ & $8.5 \pm 0.3$ & \\
\hline \multirow[t]{2}{*}{ 第 2 群 } & (1) & $0.1(n=5)$ & $8,8,9,9,13$ & $9.4 \pm 0.9$ & N.S. \\
\hline & (2) & $0.2(n=7)$ & $7,8,8,9,9,9,10$ & $8.6 \pm 1.0$ & N.S. \\
\hline \multirow[t]{3}{*}{ 第3 群 } & (1) & $0.05(n=6)$ & $9,9,9,10,12,12$ & $10.6 \pm 0.6$ & N.S. \\
\hline & (2) & $0.1(n=6)$ & $9,11,11,13,15,15$ & $12.3 \pm 1.0$ & N.S. \\
\hline & (3) & $0.2(n=5)$ & $10,11,14,21,27$ & $16.6 \pm 3.2$ & $<0.05$ \\
\hline 第4 群 & & $0.2(n=5)$ & $8,9,9,9,15$ & $10.0 \pm 1.3$ & N.S. \\
\hline
\end{tabular}

写真 4 移植後 7 日目腎生検 (CT $0.2 \mathrm{mg} / \mathrm{kg}$ 連続投 与群）系球体の細胞浸潤は少なく，構造はよく保た れ，間質の細胞浸潤は軽度で尿細管の払張を軽度認 める. $(\mathrm{a}: \times 80, \mathrm{~b}: \times 320)$

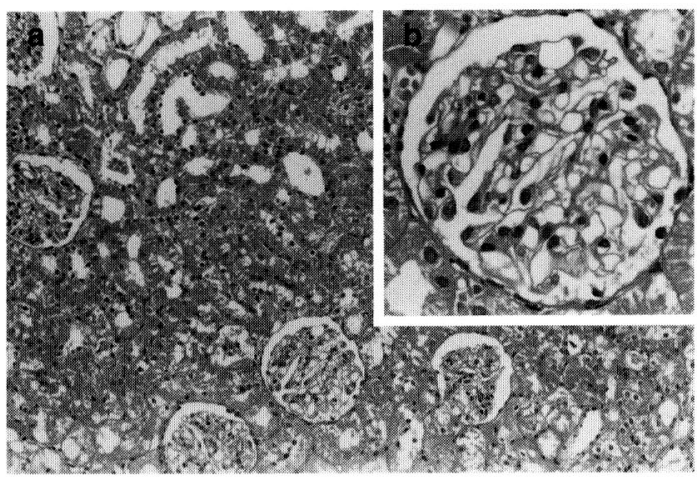

3.2 日と投与量の増加とともに生存日数が延長する傾 向がみられ，0.2mg/ $\mathrm{kg} /$ day 投与では非投与群に比べ て有意に（p<0.05）生存日数の延長がみられた（表 1)。また術後 7 日目の血清クレアチニン值は，0.05， $0.1,0.2 \mathrm{mg} / \mathrm{kg} / \mathrm{day}$ 投与群では各々 $3.9 \pm 0.8,2.3 \pm$ $0.6,1.1 \pm 0.2 \mathrm{mg} / \mathrm{dl}$ と $0.1,0.2 \mathrm{mg} / \mathrm{kg} / \mathrm{day}$ 投与群は 非投与群と比べて有意に（p<0.01）低值を示した（表 2 ). 移植後 7 日目の移植腎生検の病理組織学的所見で も，0.1，0.2mg/kg/day 投与群では，間質への細胞浸 潤は著明に抑制されて扣り，糸球体や尿細管の変化も 軽度であった(写真 4 )。移植後第 3 日目からCT を投 与し始めた第 4 群では, 生存日数は $10.0 \pm 1.3$ 日と非投 与群と比べて有意な生存日数の延長はみられなかった が(表 1), 移植後 7 日目の血清クレアチニン值は2.1土 $0.4 \mathrm{mg} / \mathrm{dl}$ と非投与群に比べて有意に（ $\mathrm{p}<0.01 ）$ 低值 をしめした(表 2 )。亦た，移植後 7 日目の移植腎生検 では血管周用に細胞浸潤はみられるが，糸球体や尿細
表 2 CT 連続投与群のラット腎同種移植後 7 日目の 血清クレアチニン値

\begin{tabular}{ccccc}
\hline 群 & $\mathrm{CT}(\mathrm{mg} / \mathrm{kg} / \mathrm{day})$ & 血清クレアチニン值 $(\mathrm{mg} / \mathrm{dl})$ & P value \\
\hline 第1群 & 0 & $(\mathrm{n}=4)$ & $6.0 \pm 0.5$ & \\
\hline 第3群 & (1) & $0.05 \quad(\mathrm{n}=6)$ & $3.9 \pm 0.8$ & N.S. \\
& (2) & $0.1 \quad(n=6)$ & $2.3 \pm 0.6$ & $<0.01$ \\
& (3) & $0.2 \quad(n=5)$ & $1.1 \pm 0.2$ & $<0.01$ \\
\hline 第4群 & & $0.2 \quad(n=5)$ & $2.1 \pm 0.4$ & $<0.01$ \\
\hline
\end{tabular}

写真 5 移植後 7 日目腎生検 (CT $0.2 \mathrm{mg} / \mathrm{kg}$, 移植後 3 日目から投与開始した群）血管周囲に細胞浸潤は みられるが, 糸球体や尿細管の変化は軽度であった。 (a: $\times 80, b: \times 160)$

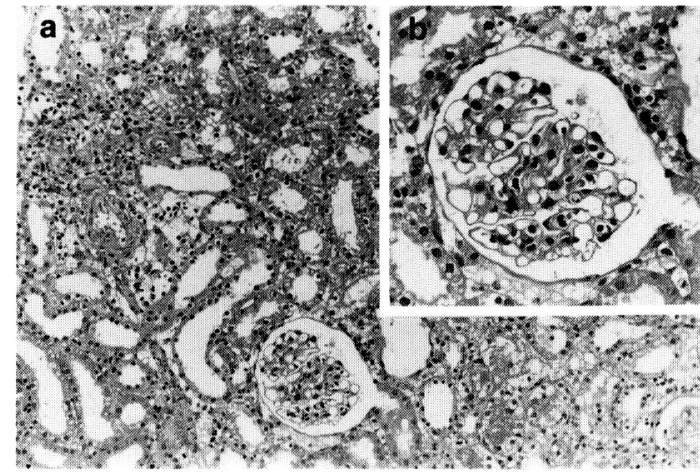

管の変化は軽度であった（写真 5$)$.

考察

CT はコレラ菌から分泌される分子量 86,0000 蛋白 であり，A，Bのサブニニットから成り立っている4). 細胞表面に到達した後，まずCTの B サブュニットが そのリセプターである細胞表面の $\mathrm{GM}_{1}$ ガングリオシ ドに結合し，次にそこに形成された poreから A サブ ユニットが細胞内に進入する. $\mathrm{A}$ サブユニットはアデ ニレートサイクラーゼを持続的に活性化する作用を もっており, 細胞内の c-AMP 濃度を上昇させ, その細 胞に特有な生物学的機能を発現させるとされている. CTの免疫系の細胞に対する作用としては, 細胞障害 性リンパ球の産生 ${ }^{8)}$ と機能発現の抑制 ${ }^{9)}$, IL-2の産生及 び IL-2に対する反応生の抑制 ${ }^{10)}, \mathrm{NK}$ 活性の抑制 ${ }^{11)}$ ど様々な作用を有することが報告されている。すた最 近では，c-AMPを介さずにB サブユニットのみでも 
マイトーゲンや抗原刺激に対するリンパ球の増殖反応 を抑制する機構も報告されている(12)13). CT 投与によ るマウスの免疫系に対する影響について Morse ら ${ }^{14)}$ は, CT $1 \mu \mathrm{g}$ の静脈内投与により末梢血, 胸腺, 脾内 のリンパ球の減少がみられたと報告している。これは 副腎を摘出したマウスではみられなかったため，CT が副腎皮質を刺激し，ステロイドの分泌を促したため ではないかとしている，本実験においてもコルチゾン に感受性の強い胸腺皮質の未熟なリンパ球が消失し， コルチゾン抵抗性の胸腺髄質のリンパ球は余り影響を 受けていないことや，CT のリセプターである $\mathrm{GM}_{1}$ ガ ングリオンドは髄質に選択的に存在する ${ }^{15}$ にもかかわ らず，髄質のリンパ球は余り影響を受けていないこと などから, in vivoに拈けるCT のリンパ球に対する作 用は，直接作用ではなく，副腎皮質を介したものと思 われた。腎移植の臨床において胸腺摘除や，脾摘除が 移植腎の生着率を向上させたとの報告もあり，本実験 でもCT が免疫反応を担当するいわゆる“lymphoid mass”である胸腺, 脾, 末梢血のリンパ球を減少させる ことにより拒絶反応の抑制に関与している可能性も考 えられた。 また，末梢血においてはCT 投与により赤 血球が減少しないこと, 多核白血球も減少せずにむし ろ増加していることから，CTはアザチオプリンやサ イクロフォスファマイドなどの免疫抑制剤と異なり骨 髄抑制作用はないるのと思われた。尚，多核白血球が 増加する原因として Morse ら ${ }^{14)}$ は CT を精製する際 にごく微量混入するエンドトキシンのためではないか としている。

MLR に対してCTは $0.01 \mu \mathrm{g} / \mathrm{ml}$ の低濃度で $47 \%$ の 抑制率を示し, $10 \mu \mathrm{g} / \mathrm{ml}$ では $97 \%$ とほとんど完全にこ れを抑制した。しかしながら $10 \mu \mathrm{g} / \mathrm{ml}$ の CT でも培養 開始後72,96時間後に添加した場合では\%抑制率は49, 21\%とその効果は低下した。この CT の MLR に対す る抑制効果の時間依存性が，CT とリンハ球との接触 時間の差によるものか，あるいはCT の MLRにおけ る存在時期の違いによるものかは今回の実験からだけ では判定できない，細胞内の c-AMP 濃度の上昇はリ ンパ球の増殖反応を抑制するが，この場合もリンパ球 の増殖反応の初期から c-AMP 濃度が上昇しているこ とが必要であり, c-AMP 濃度の上昇の時期が遅いほ ど抑制効果は低下寸るとされている ${ }^{16}$. CT も細胞内 の c-AMP 濃度を上昇させることにより作用すること から，この CT の MLR 抑制効果の時間依存性はCT の存在時期の差によるものである可能性が高いと思わ
れた。

Henny ら゙9は, CT が細胞障害性リンパ球を抑制す ることに注目し，拒絶反応の抑制に有効であるか否か を，マウス同種皮膚移植モデルを用いて実験を行って いる。彼らは CT $1 \mu \mathrm{g}$ を皮膚移植と同時に，あるいは 移植後 $1 ， 2$ または 4 日目に腹腔内に投与したが, 皮 膚移植片の生着日数の延長はみられなかったと報告し ている、また, Warren ら ${ }^{17)} は$ 同様にマウスの同種皮膚 移植モデルで CT $1 \mu \mathrm{g}$ を移植後第 6,9 日目に静脈内 に 2 回投与し,生着日数が非投与群の $13.2 \pm 0.3$ 日から $\mathrm{CT}$ 投与群の $17.4 \pm 1.2$ 日と有意に延長したと報告し ている。鶴ら $\left.{ }^{18}\right)$ は, 皮膚移植の前日に CT $1 \mu \mathrm{g}$ を静脈 内に投与し, 非投与群の $16.1 \pm 1.2$ 日と比べ投与群 $173.5 \pm 23.9$ 日と著明に生着日数が延長したと報告し ている，皮膚移植以外の実験モデルとしては， Ljungstrom ら ${ }^{19)}$ がマウスの心同種移植をモデルとしてCT の拒絶反応抑制効果を調べているが，やはり移植前日 に $1 \mu \mathrm{g}$ を静脈内に投与したときに生着日数は延長する が，移植後 $0 ， 1 ， 7$ 日目に投与した場合には生着日 数の延長はみられなかったと報告している。しかし Ljungstrom らの方法は, 心筇片を直接皮下に移植し たものであり，拒絶反応の様式としては血管茎を有す る臓器移植のモデルというよりも皮膚移植のそれに近 いものであり, 血管茎を有する臓器移植のモデルとし て, ラットの腎同種移植を用いて CT の拒絶反応抑制 効果を調べたのは今回が初めてと思われる.

CTの投与経路については, 腹腔内投与では $0.1 \sim 0.2 \mathrm{mg} / \mathrm{kg} / \mathrm{day}$ の投与量では著明な腸管の浮腫 や腹水の貯留などが起こり， $3 \sim 4$ 日で死亡するため 拒絶反応を抑制するのに必要な量を投与することはで きなかった，CTを血管内に投与した場合には，CT の もつ血管透過性六進作用 ${ }^{20}$ により血管の周囲には著明 な浮腫を来たし，血管内に連日投与することは困難で あった．皮下投与を行った場合には，やはり投与した 局所に浮腫を生じたが, これは数日で吸収されるので, 投与する部位を毎回変えることで連日投与は可能で あった。

鶴ら ${ }^{18)}$ は移植前日の 1 回投与で皮膚移植が長期生着 するメカニズムとして, 移植後早期には非特異的な免 疫抑制, その後はドナー特異的なサプレッサー細胞に より拒絶反応が抑制されるためではないかとしてい る. 今回の実験では移植前日の 1 回投与では腎移植後 の拒絶反応を抑制できなかったが，これは皮膚移植と， 腎のように血管茎を有する臟器移植とでは, 抗原量, 
感作の起こる時期と部位, revascularization の起こる 時期など拒絶反応の様式が異なっており ${ }^{21)}$ ，腎移植で は CT の 1 回投与のみでは免疫抑制剂の量としては不 十分なのではないかと思われた。そこで，シクロスポ リンや FK-506などの免疫抑制剂の動物実験の際に投 与されるのと同様に移植後 2 週間の継続投与を試み た. その結果， 1 日投与量を $0.05,0.1,0.2 \mathrm{mg} / \mathrm{kg}$ と 増量するにつれて生着日数が延長し， $0.2 \mathrm{mg} / \mathrm{kg}$ で非 投与群と比べて有意に生着日数が延長した. MLRに おいてCT を添加する時期が遅れるほどその効果が減 弱することや，腎移植後 3 日目以降に投与した場合に はその免疫抑制効果が弱くなることなどから，CT は 拒絶反応の induction が起こってから投与されても， その免疫抑制効果は不十分であり, 主としてTリンパ 球による移植抗原の認識 ${ }^{12)}$ や，その後に起るへルパー T リンパ球による IL-2の産生抑制など22), 拒絶反応の early phase に作用している可能性が高いと考えられ る.

$\mathrm{CT} 0.2 \mathrm{mg} / \mathrm{kg}$ 投与群の 7 日目の血清クレアチニン 值や, 移植腎生検の所見をみる限り, この時点では拒 絶反応は完全に抑制されて扣り，その後 CT の投与を 続けているにもかかわらず死亡するラットがみられた が，その原因としてはCT に対する中和抗体の出現や CT そのもののもつ毒性による可能性が考えられた。 現在臨床に拀いて急性拒絶反応の治療に用いられてい る OKT3は, ヒト $\mathrm{T}_{3}$ 抗原認識複合体に対するマウス 由来モノクローナル抗体であるが，やはり投与後高率 に中和抗体が産生され，その効果が低下するとされて いる ${ }^{23)}$. CT の場合も異種蛋白である CT に対する中 和抗体が産生され，その効果が不定となる可能性が考

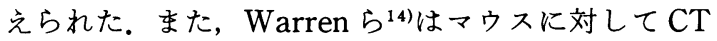
$0.5,1 \mu \mathrm{g}$ を 2 回静脈内に投与したところ死亡率はそれ ぞれ $44 ， 52 \%$ と高率であったと報告しており，著者の 実験でも死亡したラットの臓器を検索した結果では CTによる死因となるような組織学的な変化は認めら れなかったが，血清クレアチニンの上昇がみられない まま死亡するラットもあり，CT そのもののもつ毒性 による死亡の可能性も考えられた。

今回の実験で CT はラット腎同種移植において拒絶 反応を抑制することが明かとなった。CTのヒトへの 応用に関しては, 毒性や中和抗体の問題が残されてい る.しかし，これらの問題については今後他剤との併 用による小量投与などにより解決可能と思われるの で, CT は臓器移植における新しい免疫抑制剂の一つ
となり得ると考える。

\section{結語}

CT の免疫抑制効果についてラット腎同種移植モデ ルを用いて実験を行い，以下のような結果を得た。

1. CT の投与により末梢血, 胸腺, 脾臓内のリンパ 球は著しく減少したが，骨髄抑制作用はみられなかっ た。

2.CTはMLRを濃度依存性に抑制した。

3. CT の MLR に対する抑制は添加時期により経 時的に減弱し，時間依存性を示した。

4. CT の移植前 1 回投与ではラット腎同種移植後 の生存日数は延長しなかった。

5.CT を移植後 3 日目から連続投与した場合には, ラット腎同種移植後の生存日数は延長したが有意差を 認めなかった。

6. CT の移植当日からの連続投与では, ラット腎同 種移植後の生存日数は 1 回投与量の増加とともに延長 し， $0.2 \mathrm{mg} / \mathrm{kg} / \mathrm{day}$ では非投与群と比べ有意に（ $\mathrm{p}<$ 0.05）延長した.

本論文の要旨は, 第76回日本泌尿器科学会総会 (盛岡), 及び第84回米国泌尿器科学会（Dallas）に扣いて報告した.

稿を終えるにあたり，ご指導を賜った田崎 寛教授(慶応 義塾大学）と御校閲を賜りました中村 宏教授に深謝致し ます。また，折りにふれ御助言を賜りました村井 勝助教 授, 研究に御協力いただきました家田和夫講師に心から感 謝致します。

\section{文 献}

1) Calne, R.Y., Rollers, K., White, D.J.G., Thiru, S., Evans, D.B., McMaster, P., Dunn, D.C., Craddock, G.N., Henderson, R.G., Aziz, S. and Lewis, P.: Cyclosporin A initially as the only immunosuppressant in 34 patients of cadaveric organs. 32 kidneys, 2 pancreases and 2 livers. Lancet, 2, 1033-1036, 1979.

2) Ochiai, T., Nakajima, K., Nagata, M., Hori, S., Asano, T. and Isono, K.: Studies of the induction and maintenance of long-term graft acceptance by treatment with FK 506 in heterotopic cardiac allotransplantation in rats. Transplantation, 44, 734-738, 1987.

3) Amemiya, H., Suzuki, S., Manabe, H., Fukao, K., Iwasaki, Y., Dohi, K., Isono, K., Orita, K. and Yamanaka, N.: 15-deoxyspergualin as an immunosuppressive agent in dogs. Transplant. Proc., 20, 229-232, 1988.

4) Holmgren, J. : Action of cholera toxin and the prevention and treatment of cholera. Nature, 
292, 413-417, 1981.

5) Vischer, T.L. and LoSpalluto, J.J.: The differential effect of cholera toxin on the lymphocyte stimulation induced by various mitogens. Immunology, 29, 275-282, 1975.

6) Chisari, F.V., Northrup, R.S. and Chen, L.C. : The immunomodulating effect of cholera enterotoxin on the immune response. J. Immunol., 113, 729-739, 1974.

7) Lee, S.: An improved technique of renal transplatation in rat. Surg., 61, 771-773, 1967.

8) Tsuru, S., Nomoto, K., Oka, M. and Zinnaka, Y.: Effects of cholera toxin on the lymphoid system. III. In vivo generation of cytotoxic lymphocytes. J. Clin. Lab. Immunol., 4, 209-214, 1983.

9) Henney, C.S., Lichtenstein, L.M., Gillespie, E. and Rolley, R.T.: In vivo suppression of the immune response to alloantigen by cholera enterotoxin. J. Clin. Invest., 52, 2853-2857, 1973.

10) Lycke, N., Bromander, A.K., Ekman, L., Karlsson, U. and Holmgren, J.: Cellular basis of immunomodulation by cholera toxin in vitro with possible association to the adjuvant function in vivo. J. Immunol., 142, 20-27, 1989.

11) Fuyama, S., Naiki, M. and Sendo, F.: The mechanism of cholera toxin induced suppression on natural killer cytotoxicity. Gann, 73, 798-804, 1982.

12) Imboden, J.B., Shoback, D.M., Pattison, G. and Stobo, J.D. : Cholera toxin inhibits the T-cell antigen receptor mediated increases in inositol triphosphate and cytoplasmic free calcium. Proc. Natl. Acad. Sci. U.S.A., 83, 5673-5677, 1986.

13) Woogen, S.D., Ealding, W. and Elson, C.O. : Inhibition of murine lymphocyte proliferation by B subunit of cholera toxin. J. Immunol., 139, 3764-3770, 1987.

14) Morse, S.I., Stearns, C.D. and Goldsmith, S.R. : Lymphocyte depletion induced by cholera toxin ; relationship to adrenal cortical function.
J. Immunol., 114, 665-670, 1975.

15) Bouchom, B., Iwamori, M., Masago, H. and Nagai, Y.: Selective expression of cholera toxin receptor in rat medullary thymocytes. Cell Struct. Funct., 12, 339-344, 1987.

16) Smith, J.W., Steiner, A.L. and Parker, C.W.: Human lymphocyte metabolism. Effects of cyclic and noncyclic nucleotides on stimulation by phytohemagglutinin. J. Clin. Invest., 50, 442-448, 1971.

17) Warren, K.S., Mahmoud, A.A.F., Boros, D.L., Rall, T.W., Mandel, M.A. and Carpenter, C.C.J. Jr.: In vivo suppression by chorela toxin of cell-mediated and foreign body inflammatory responses. J. Immunol., 112, 996-1007, 1974.

18) Tsuru, S., Taniguchi, M., Shinomiya, N., Takemura, T. and Togami, M. : Histoincompatible skin and marrow grafts in mice given cholera toxin. Transplant. Proc., 21, 1158-1160, 1989.

19) Ljungstrom, I., and Holmgren, J. : In vivo suppression of allograft rejection by cyclic AMP increasing agents. Int. Archs. Allergy Appl. Immun., 58, 99-104, 1979.

20) Craig, J.P.: A permiability factor (toxin) found in cholera stools and culture filtrates and its neutralization by convalescent cholera sera. Nature, 207, 614-616, 1965.

21) Morris, P.J. : Kidney Transplantation, 3rd ed., p. 15-36, W.B. Saunders Co., Philadelphia, 1988.

22) Munoz, E., Zubiaga, A.M., Merrow, M., Sauter, N.P. and Huber, B.T. : Cholera toxin discriminates between $T$ helper 1 and 2 cells in $T$ cell receptor-mediated activation: Role of c-AMP in $\mathrm{T}$ cell proliferation. J. Exp. Med., 172, 95-103, 1990.

23) Bach, J.F. and Chatenoud, L.: Immunologic monitoring of orthoclone OKT-3 treated patients: The problem of antimonoclonal immune response. Transplant. Proc., 19, 17-20, 1987.

（1991年 6 月 13 日受理，特別掲載） 